\title{
Morphogenetic Potential of Tomato (Lycopersicon esculentum) cv. 'Arka Ahuti' to Plant Growth Regulators
}

\author{
Kanakapura K. NAMITHA, Pradeep S. NEGI* \\ Fruit and Vegetable Technology Department, CSIR-Central Food Technological Research Institute, \\ Mysore-570020, India; psnegi@cftri.res.in (*corresponding author)
}

\begin{abstract}
A highly reproducible in vitro regeneration method for tomato (Lycopersicon esculentum Mill.) cultivar 'Arka Ahuti' was established by using hypocotyl, leaf and cotyledon explants from in vitro raised seedlings on Murashige and Skoog medium supplemented with different concentrations and combinations of hormones 6-Benzylamino purine ( 2 to $4 \mathrm{mg} / \mathrm{L})$ and Indole-3-acetic acid $(0.1$ to $1 \mathrm{mg} / \mathrm{L})$. The medium supplemented with $2 \mathrm{mg} / \mathrm{L}$ 6-benzylamino purine and $0.1 \mathrm{mg} / \mathrm{L}$ indole-3-acetic acid was found to be the best for inducing direct shoot regeneration and multiple shoots per explant from hypocotyl explants. Callus induction was observed in all the explants and regeneration of shoots was also promoted by all these combinations. Shoots were transferred to the elongation medium which also induced $100 \%$ rooting. After hardening, plants were transferred to soil. Thus, a tissue culture base line was established for 'Arka Ahuti cultivar of tomato for obtaining direct regeneration using hypocotyl, leaf and cotyledon as explants.
\end{abstract}

Keywords: BAP, cotyledon, IAA, hypocotyl explant, regeneration

\section{Introduction}

Tomato (Lycopersicon esculentum Mill.), a member of the Solanaceae family is the second most popular and highly nutritive vegetable crop after potato (Mamidala and Nanna, 2011). Though a temperate plant, it is extensively cultivated in the tropical and subtropical regions of the world such as South Europe, North and South America, India, China, and Japan round the year, with an annual production of 150 million metric tons in the year 2010-11. India produced 168 lakh metric tons in 8.6 lakh hectare areas in the year $2010-11$, contributing to $11 \%$ of the total world production (Indian Horticultural Database 2011). Tomato is a rich source of lycopene (Shi and Le Maguer, 2000; Fraser and Bramley, 2004), which is the most powerful antioxidant in the carotenoid family. Lycopene protects humans from free radicals that are generated in many parts of the body (Gerster, 1997) and is also associated with decrease in the risk of chronic diseases such as cancer and cardiovascular disease (Rao and Rao, 2007). Tomato is also a rich source of vitamin $\mathrm{C}$, vitamin B and a good source of $\beta$-carotene (Shi and Le Maguer, 2000). Tomato has been used extensively as a genetic model for crop improvement (Namitha and Negi, 2010).

In vitro regeneration through organogenesis and somatic embryogenesis are being used for multiplication of genetically identical clones and it is an integral part of genetic transformation procedures (Plastira and Perdikaris, 1997; Oktem et al., 1999; Gubis et al., 2004; Rashid and Bal, 2010). Specific plant growth regulator requirements for each genotype make the tissue culture task in tomato quite difficult and researchers need to deal with each genotype individually (Bhatia et al., 2004; Sheeja et al., 2004). Cultivar 'Arka Ahuti' is a processing cultivar, which is suitable for puree making due to its higher total soluble solid content and it has high lycopene content also (Namitha et al., 2011; Jyothi et al., 2012). Many laboratories are engaged in research on tomato to manipulate the nutrient quality through transformation studies; however tomato transformation is variable from genotype to genotype (Bhatia et al., 2004; Mamidala and Nanna, 2011). Development of an efficient in vitro regeneration system for effective genetic transformation of a processing variety is essential for its commercial exploitation. The present study describes a simple and efficient procedure for enhanced regeneration of tomato cultivar 'Arka Ahuti'.

\section{Materials and methods}

\section{Plant material}

Seeds of tomato (L. esculentum) var. 'Arka Ahuti', obtained from Indian Institute of Horticulture Research (IIHR), Bangalore were soaked under running tap water for $24 \mathrm{~h}$. These seeds were surface sterilized with a mixture of $0.4-0.6 \%$ sodium hypochlorite and Tween 20 (0.1\%) for $3 \mathrm{~min}$, followed by wash with sterile distilled water thrice and then dried on sterile tissue paper. These seeds were allowed to germinate in plastic containers (Phyta jar, HIMEDIA, Mumbai) containing $40 \mathrm{~mL}$ of Murashige and Skoog (MS) medium with MS salts (Murashige and Skoog, 1962), $100 \mathrm{mg} / \mathrm{L}$ myoinositol, MS vitamins (2 $\mathrm{mg} / \mathrm{L}$ thiamine $\mathrm{HCl}, 0.5 \mathrm{mg} / \mathrm{L}$ pyridoxine $\mathrm{HCl}, 0.5 \mathrm{mg} / \mathrm{L}$ 
nicotinic acid), and 3\% (w/v) sucrose. The $\mathrm{pH}$ of the MS medium was adjusted to 5.8 with either $1 \mathrm{~N}$ hydrochloric acid $(\mathrm{HCl})$ or sodium hydroxide $(\mathrm{NaOH})$ solution and was solidified with $0.8 \%(\mathrm{w} / \mathrm{v})$ agar. Seeds were cultivated initially for two days in dark at $25 \pm 1{ }^{\circ} \mathrm{C}$ temperature and then they were maintained under photoperiod of $16 \mathrm{~h}$ illumination with light intensity of $50 \mu \mathrm{mol} / \mathrm{m}^{2} / \mathrm{s}$, at $25 \pm$ $2^{\circ} \mathrm{C}$. Cotyledons from $8 \mathrm{~d}$ old seedlings and primary leaves (0.5 to $2 \mathrm{~cm}$ long), leaf explants $\left(1.0 \mathrm{~cm}^{2}\right)$ and hypocotyls ( 0.5 to $0.8 \mathrm{~cm}$ long) from three week-old seedlings were aseptically excised and both ends were cut.

\section{Regeneration media and culture conditions}

The hypocotyl, cotyledon and leaf explants were cultured on MS basal medium supplemented with $4 \mathrm{mg} / \mathrm{L}$ 6-Benzyl amino purine (BAP) and $1 \mathrm{mg} / \mathrm{L}$ Indole-3-acetic acid (IAA) (Medium A); BAP $3 \mathrm{mg} / \mathrm{L}$ and IAA $1 \mathrm{mg} / \mathrm{L}$ (Medium B) and BAP $2 \mathrm{mg} / \mathrm{L}$ and IAA $0.1 \mathrm{mg} / \mathrm{L}$ (Medium $\mathrm{C}$ ). The media were adjusted to $\mathrm{pH} 5.8$ either with $1 \mathrm{~N}$ $\mathrm{HCl}$ or $1 \mathrm{~N} \mathrm{NaOH}$ before addition of $0.8 \%(\mathrm{w} / \mathrm{v})$ agar and autoclaved at $121^{\circ} \mathrm{C}$ under 15 Psi for $20 \mathrm{~min}$. All the cultures were incubated at $25 \pm 2{ }^{\circ} \mathrm{C}$ under $16 / 8 \mathrm{~h}$ (dark/ light) photoperiod with light intensity $40-50 \mu \mathrm{mol} / \mathrm{m}^{2} / \mathrm{s}$ provided by cool white fluorescent lights (Phillips India Ltd.). Explants were sub-cultured on the same fresh medium at every four weeks for further proliferation. All the experiments are conducted in triplicates.

\section{In vitro rooting and acclimatization}

Micro-shoots (2 to 3 nodes) developed from hypocotyl, cotyledon and leaf explants were excised and transferred on to MS medium fortified with $1 \mathrm{mg} / \mathrm{L}$ IAA. In vitro rooted plantlets were taken out from the culture tubes and washed with sterile distilled water to remove the remains of medium. These were transferred to nursery bags containing sterile vermiculite, sand and soil in the ratio 1:1:1 and covered with polythene bags to maintain the relative humidity (70 to $80 \%$ ). The acclimatized plantlets were later shifted to pots.

\section{Statistical analysis}

The experiment was repeated thrice with 8-10 explants (depending on the explant type). The data presented are averages of mean of three independent experiments with standard deviation. Significance of differences between the results was estimated by Analysis of Variance (ANO-
VA) and variation among means was analyzed by Duncan's multiple range test (DMRT) (Gomez and Gomez, 1984).

\section{Results}

Shoots were observed after 15-20 days of culture in all three media (Fig. 1a, 1b and 1c). Out of the different hormonal combinations tried for in vitro shoot regeneration from hypocotyls, leaf and cotyledon explants of 'Arka Ahuti' cultivar of $L$. esculentum, the combination of BAP $2 \mathrm{mg} / \mathrm{L}$ and IAA $0.1 \mathrm{mg} / \mathrm{L}$ (Medium C) was best (Fig. 1c) (Tab. 1), followed by Medium B (BAP $3 \mathrm{mg} / \mathrm{L}$ and IAA $1 \mathrm{mg} / \mathrm{L})$ (Fig. 1b). The regeneration frequency was found highest in medium $C$ for hypocotyls (73.67 $\pm 1.53 \%)$ and cotyledon $(61.33 \pm 0.58 \%)$, and leaf explants showed highest regeneration in medium A (43.67 $\pm 2.08 \%)$ (Tab. 2). Hypocotyls, cotyledons as well as leaf explants did produce multiple shoots (Fig. $2 \mathrm{a}, 2 \mathrm{~b}, 2 \mathrm{c}$ respectively); single shoots were proliferated with 3-5 nodes in the combination of BAP $2 \mathrm{mg} / \mathrm{L}$ and IAA $0.1 \mathrm{mg} / \mathrm{L}$ (Medium C) (Fig. 1c). The proliferation of shoots started after 6-8 days of culture from hypocotyls and cotyledon explants on the same medium. It was found that MS medium containing BAP $4 \mathrm{mg} / \mathrm{L}$ and IAA $1 \mathrm{mg} / \mathrm{L}$ (Medium A) were less effective for obtaining response from leaf explants (Tab. 1). However, MS media with BAP $2 \mathrm{mg} / \mathrm{L}$ and IAA $0.1 \mathrm{mg} / \mathrm{L}$ (Medium C) combination gave rise to long shoots with a maximum number of nodes per culture from hypocotyls $(13.3 \pm 0.81)$ and cotyledon $(11.7 \pm 0.35)$ explants, respectively with $100 \%$ response from shoots after 6 weeks of culture (Fig. 1c). All the three combinations in all the three explants showed positive response of callusing (Fig. 1f).

Tab. 1. Number of shoots formed per explant on MS medium supplemented with different hormones in the 'Arka Ahuti' cultivar

\begin{tabular}{cccc}
\hline Explants & Medium A & Medium B & Medium C \\
\hline Hypocotyl & $5.4 \pm 0.27^{\mathrm{c}}$ & $7.4 \pm 0.33^{\mathrm{b}}$ & $13.3 \pm 0.81^{\mathrm{a}}$ \\
Leaf & $4.8 \pm 0.33^{\mathrm{c}}$ & $6.2 \pm 0.41^{\mathrm{b}}$ & $8.3 \pm 0.25^{\mathrm{a}}$ \\
Cotyledon & $3.5 \pm 0.31^{\mathrm{c}}$ & $6.6 \pm 0.16^{\mathrm{b}}$ & $11.7 \pm 0.35^{\mathrm{a}}$ \\
\hline
\end{tabular}

The data $(n=3)$ were taken after 6 weeks of culture. Values (mean \pm SD) in each row followed by same letter are not significantly different at $\mathrm{p} \leq 0.05$.

Medium A-BAP $4 \mathrm{mg} / \mathrm{L}$ and IAA $1 \mathrm{mg} / \mathrm{L}$; Medium B-BAP $3 \mathrm{mg} / \mathrm{L}$ and IAA $1 \mathrm{mg} / \mathrm{L}$; Medium C-BAP $2 \mathrm{mg} / \mathrm{L}$ and IAA $0.1 \mathrm{mg} / \mathrm{L}$

Tab. 2. Shoot length and regeneration frequency of explants on MS medium supplemented with different hormones in the 'Arka Ahuti' cultivar

\begin{tabular}{|c|c|c|c|c|c|c|}
\hline \multirow{2}{*}{ Explants } & \multicolumn{3}{|c|}{ Average Shoot length (mm) } & \multicolumn{3}{|c|}{ Regeneration frequency (\%) } \\
\hline & Medium A & Medium B & Medium C & Medium A & Medium B & Medium C \\
\hline Hypocotyl & $8.33 \pm 0.25^{\mathrm{a}}$ & $7.43 \pm 0.68^{b}$ & $8.63 \pm 0.15^{a}$ & $64.33 \pm 2.08^{c}$ & $70.67 \pm 2.52^{a}$ & $73.67 \pm 1.53^{a}$ \\
\hline Leaf & $4.07 \pm 0.25^{\mathrm{a}}$ & $3.33 \pm 0.12^{c}$ & $3.67 \pm 0.12^{b}$ & $43.67 \pm 2.08^{a}$ & $32.33 \pm 1.53^{c}$ & $38.33 \pm 0.58^{b}$ \\
\hline Cotyledon & $7.83 \pm 0.31^{\mathrm{a}}$ & $6.47 \pm 0.60^{b}$ & $8.20 \pm 0.10^{\mathrm{a}}$ & $60.00 \pm 2.00^{\mathrm{a}}$ & $60.33 \pm 2.08^{a}$ & $61.33 \pm 0.58^{a}$ \\
\hline
\end{tabular}

The data $(\mathrm{n}=3)$ were taken after 6 weeks of culture. Values (mean $\pm \mathrm{SD}$ ) in each row for average shoot length and regeneration frequency followed by same letter are not significantly different $(p \leq 0.05)$. Medium A-BAP $4 \mathrm{mg} / \mathrm{L}$ and IAA $1 \mathrm{mg} / \mathrm{L} ;$ Medium B-BAP $3 \mathrm{mg} / \mathrm{L}$ and IAA $1 \mathrm{mg} / \mathrm{L} ; \mathrm{Medium} \mathrm{C-BAP} 2 \mathrm{mg} / \mathrm{L}$ and IAA 0.1 mg/L 


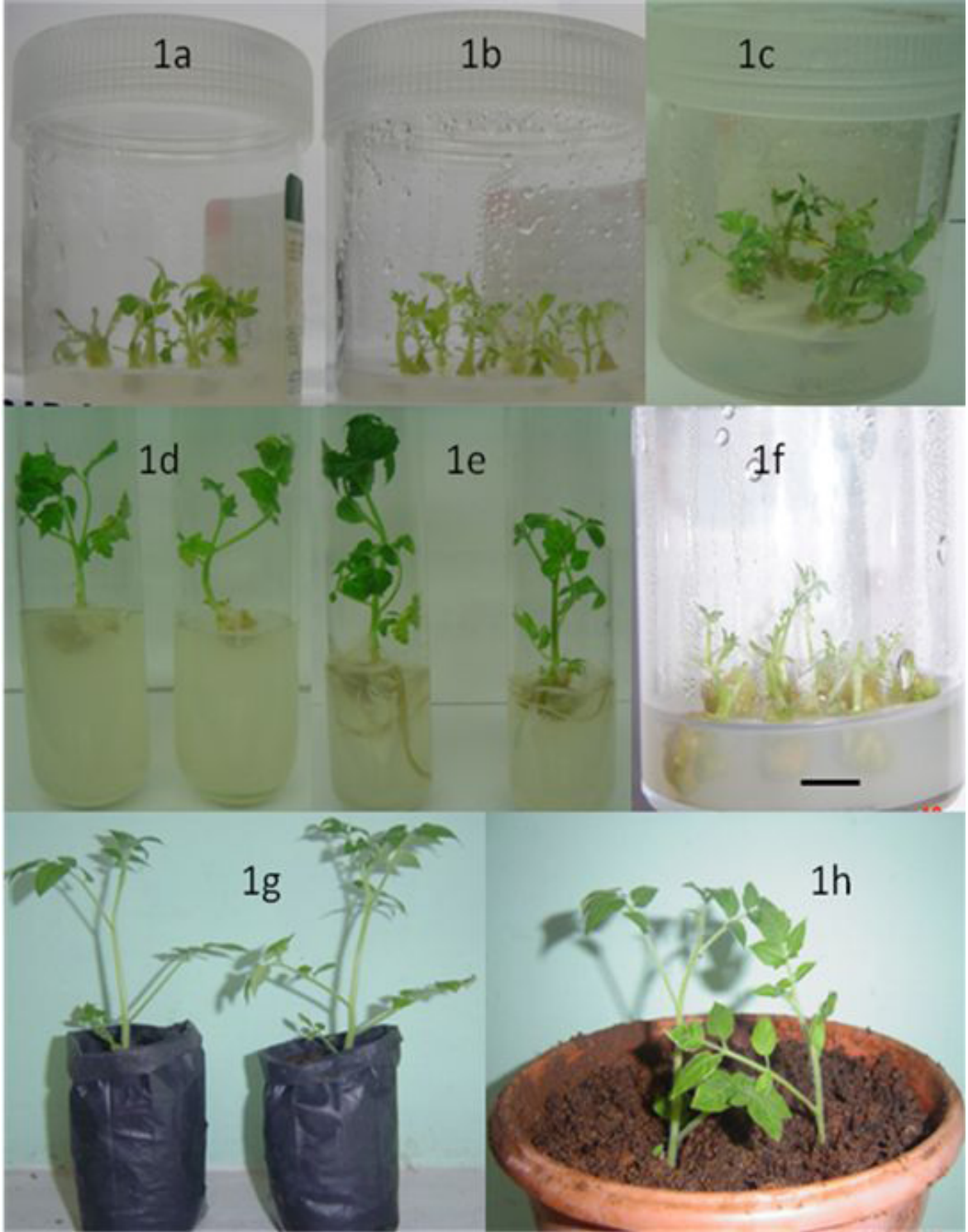

Fig. 1. In vitro culture of Lycopersicon esculentum cultivar 'Arka Ahuti'

1a) BAP $4 \mathrm{mg} / \mathrm{L}$ and IAA $1 \mathrm{mg} / \mathrm{L}$ (Medium A); 1b) BAP $3 \mathrm{mg} / \mathrm{L}$ and IAA $1 \mathrm{mg} / \mathrm{L}$ (Medium B); 1c) BAP $2 \mathrm{mg} / \mathrm{L}$ and IAA $0.1 \mathrm{mg} / \mathrm{L}$ (Medium C) showing multiple shoots; $1 \mathrm{~d}$ ) shoot elongation; 1e) Rooting of the in-vitro culture; 1f) in-vitro culture showing both callus and shoot formation; $1 \mathrm{~g}$ ) and $1 \mathrm{~h}$ ) Hardening of the plants (bar=10mm)

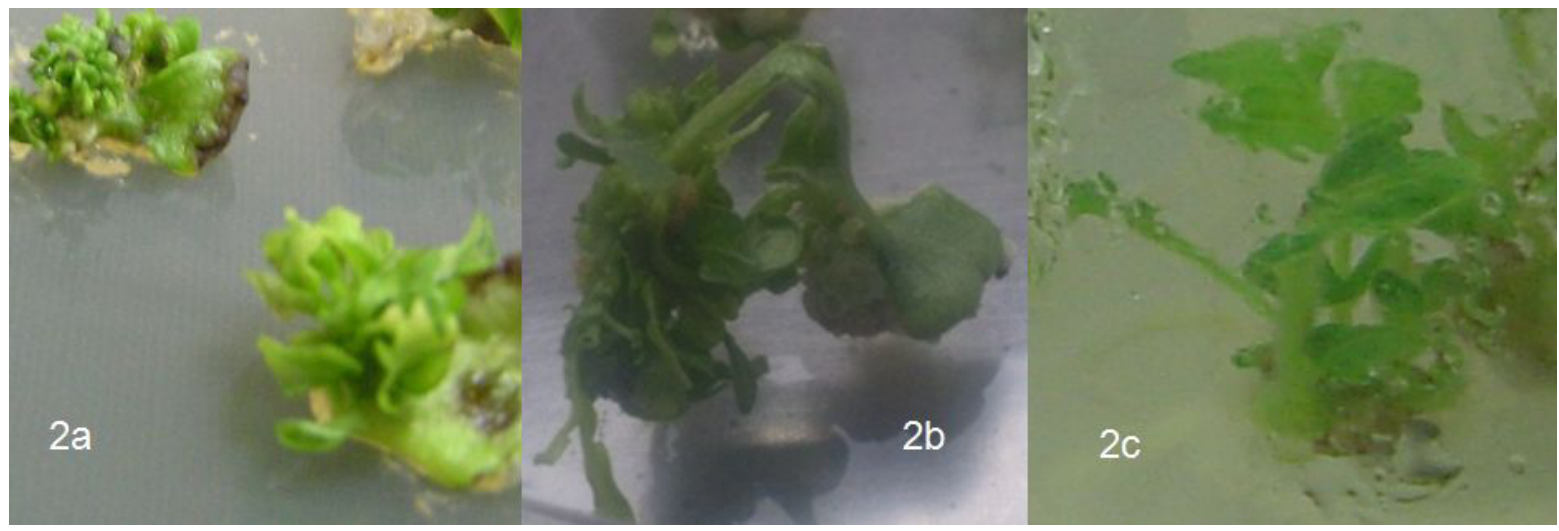

Fig. 2. Shoot bud initiation from explants [2a) hypocotyl; 2b) cotyledon; 2c) leaf] 
The primary shoots when sub-cultured on to MS medium supplemented with BAP $2 \mathrm{mg} / \mathrm{L}$ and IAA $0.1 \mathrm{mg} / \mathrm{L}$ (Medium C) showed considerable elongation of shoots with 4-7 nodes (Fig. 1d) and big green leaves $(3-3.5 \mathrm{~cm}$ length and 2-2.4 cm width). The average shoot length was found to be highest for hypocotyl explants $(8.63 \pm$ $0.15 \mathrm{~mm})$ and cotyledon explants $(8.20 \pm 0.10 \mathrm{~mm})$ in medium $C$, whereas leaf explant showed highest shoot length $(4.07 \pm 0.25 \mathrm{~mm})$ in medium A (Tab. 2). Though lower $(0.5 \mathrm{mg} / \mathrm{L})$ and higher $(6.0 \mathrm{mg} / \mathrm{L})$ ranges of BAP and IAA were tried, they were not effective both in initial and later stages of growth. Another advantage of this hormonal combination (BAP and IAA) in MS medium was the simultaneous rooting of the shoots within 45 days (Fig. 1e) without further sub-culturing onto other media for in vitro rooting. However, some shoots which did not develop roots were transferred to MS media with $1 \mathrm{mg} / \mathrm{L}$ IAA to induce root formation. A maximum of 4-5 roots per shoot with a root length of $7-9 \mathrm{~cm}$ were produced after 60 days in the same medium used for elongation. The rooted plants were transplanted ex vitro and raised in nursery bags (Fig. 1g) under green house conditions for one month, followed by their transfer to open field (Fig. 1h). Approximately $80-90 \%$ of the plantlets survived and after 4 months, the potted tissue cultured plants showed good yield which was equal to normal plants.

\section{Discussion}

In vitro culture is used in tomato in different biotechnological applications, such as clonal propagation (Gamburg and Semenova, 1997; Chen et al., 2006), production of virus-free plants (Moghaieb et al., 1999), genetic transformation (Frary and Earle, 1996; Ling et al., 1998; Park et al., 2003) and in many fundamental research programs (Hanus-Fajerska, 2000; Arrillaga et al., 2001; Gubis et al., 2004). Most of the reports about adventitious regeneration in tomato deal with induction of regeneration in hypocotyl or cotyledon explants (Rashid and Bal, 2010). In wild tomato Lycopersicon cheesmanii, regeneration of 5.8 and 6.0 shoots using leaf and cotyledon explants, respectively, were obtained when zeatin and BAP was added to the culture medium (Arrillaga et al., 2001). Hamza and Chupeau (1993) observed efficient regeneration from cotyledonary explants from 10 day old seedlings on MS media with $0.5 \mathrm{mg} / \mathrm{L}$ zeatin and $0.5 \mathrm{mg} / \mathrm{L}$ IAA in cultivar UC82B. Ichimura and Oda (1995) used the medium with $0.1 \mathrm{mg} / \mathrm{L} \mathrm{IAA}$ and $1 \mathrm{mg} / \mathrm{L}$ zeatin to study the effect of different agar concentrations and different gelling agents on shoot regeneration in cultivated tomato. They obtained adventitious shoots which grew normally producing 3.14.5 shoots per cotyledon explants in media using different gelling agents viz. $0.8 \%$ agar, $0.8 \%$ agarose and $0.2 \%$ gellan gum. Studying the in vitro organogenesis in tomato $\mathrm{cv}$. S-22, using 10-12 d cotyledonary explants, Vikram et al. (2011) obtained highest callus induction on media con- taining BAP $3 \mathrm{mg} / \mathrm{L}$ and multiple adventitious shoots on MS media with $0.1 \mathrm{mg} / \mathrm{L}$ IAA and $2.5-5.0 \mathrm{mg} / \mathrm{L} \mathrm{BAP}$, which support our results, wherein we obtained multiple shoots from hypocotyl and cotyledonary explants on MS media supplemented with BAP and IAA.

Various combinations of auxins/cytokinins have been used to study their effect on regeneration (Rao et al., 2005). Gubis et al. (2004), observed that zeatin (1 mg/L) and IAA $(0.1 \mathrm{mg} / \mathrm{L})$ supplemented media had $100 \%$ regeneration frequency with hypocotyl explants in all genotypes studied. However, we obtained a regeneration frequency of $74 \%, 71 \%$ and $64 \%$ for hypocotyls explants in medium C, B and A, respectively. Ishag et al. (2009) found that kinetin at $4 \mathrm{mg} / \mathrm{L}$ was more effective than BAP for shoot proliferation producing 2 shoots/ shoot tip explants. However, we obtained maximum regeneration in media supplemented with $3 \mathrm{mg} / \mathrm{L} \mathrm{BAP}$ and $1 \mathrm{mg} / \mathrm{L}$ IAA. The primary mode of regeneration in tomato via shoot organogenesis from callus is derived from various explants such as leaf, cotyledon, etc, and only a few studies report direct regeneration of adventitious shoots on tomato leaf explants on medium with high cytokinin/auxin ratio (Rao et al., 2005; Rashid and Bal, 2010). In the present study, synergistic action of BAP and IAA induced regeneration of multiple shoots with no visible callus from the cut ends of leaf explants, which is same as reported in above mentioned reports. Results of this experiment confirmed the positive influence of growth regulator on the number of shoots regenerated from tomato cotyledons, leaf and hypocotyls. Our experiments supported the results of other authors (Nogueira et al., 2001; Gubis et al., 2004) where most efficient medium for in vitro regeneration of tomato was induction medium supplemented with a cytokinin. Devi et al. (2008), studying the morphogenesis in 4 cultivars of tomato viz. Castle Rock, Punjab Upma, VFN-8 and IPA-3 in response to growth regulators found that MS media with $3 \mathrm{mg} / \mathrm{L} \mathrm{BAP}$ and $2.5 \mathrm{mg} / \mathrm{L}$ IAA was optimum for callus induction, plant regeneration and number of shoots per explants produced. Similarly, Selvi and Khader (1993), Villiers et al. (1993), Duzyaman et al. (1994), Chen et al. (1999), Chandel and Katiyar (2000) and Mamidala and Nanna (2011) observed that a combination of IAA + BAP to be most effective for shoot regeneration from different explants of tomato. It was observed that BAP had positive effect towards multiple shoot regeneration, a result in agreement with that of the findings of Oktem et al. (1999), Fariduddin et al. (2004) and Sarker et al. (2009). Addition of IAA was found to increase regeneration efficiency as reported earlier by Frary and Earle (1996), Gubis et al. (2003) and Cortina and Culianez-Macia (2004).

Cultivar, explant type and medium composition are considered the three main factors affecting in vitro plant regeneration in many plant species. The regeneration capacity of explants strongly depended on the cultivar and explant type (Gubis et al., 2004; Rashid and Bal, 2010; Harish et al., 2010). Gubis et al. (2004) reported that most 
224

responsive explants in most cultivars were hypocotyls and epicotyls with up to $100 \%$ regeneration and mean production of 6.3 and 6.5 shoot primordia per explants, respectively. In our study also, hypocotyl segments showed the highest shoot regeneration ability.

\section{Conclusions}

Development of an efficient regeneration protocol is a prerequisite for Agrobacterium mediated genetic transformation to be used for the genetic improvement of Lycopersicon species. Tomato regeneration is genotype, explant and media dependent. The present investigation showed that the medium containing BAP $(2 \mathrm{mg} / \mathrm{L})$ and IAA $(0.1$ $\mathrm{mg} / \mathrm{L}$ ) are better media for regeneration of hypocotyls and cotyledon explants, which can be used for successful regeneration of tomato cv. 'Arka Ahuti'.

\section{Acknowledgements}

We thank Director, CSIR-CFTRI for constant support and encouragement. KKN acknowledges CSIR, New Delhi, India, for the financial support in the form of a Senior Research Fellowship.

\section{References}

Arrilliga C, Gisbert E, Sales L, Roig MV (2001). In vitro plant regeneration and gene transfer in the wild tomato Lycopersicon cheesmanii. J Hort Sci Biotech 76:413-418.

Bhatia P, Nanjappa A, Tissa S, David M (2004). Tissue culture studies in tomato (Lycoperiscon esculentum). Plant Cell Tiss Org Cult 78:1-21.

Chandel G, Katiyar SK (2000). Organogenesis and somatic embryogenesis in tomato (Lycopersicon esculentum Mill.). Adv Plant Sci 13:11-17.

Chen HY, Zhang JH, Zhuang TM, Zhou GH (1999). Studies of optimum hormone levels for tomato plant regeneration from hypocotyl explants cultured In vitro. Acta Agric Shanghai 18: 26-29.

Chen LZ, Silva LM, da JAT (2006). Somatic embryogenesis, Plant regeneration and clonal propogation in different tissue sources of different flowering plants: monocots and dicots, 299-304 p. In: Teixeira da Silva JA (Ed.). Floriculture, Ornamental and Plant Biotechnology. Global Science Books Ltd., Middlesex UK.

Cortina C, Culianez-Macia FA (2004). Tomato transformation and transgenic plant production. Plant Cell Tiss Organ Cult 76:269-275.

Devi R, Daliwal MS, Kaur A, Bansal SS (2008). Effect of growth regulators on in vitro morphogenic response of tomato. Indian J Biotechnol 7:526-530.

Duzyaman E, Tanrisever A, Gunver G (1994). Comparative studies on regeneration of different tissues of tomato in vitro. Acta Horti 366:235-242.
Fariduddin M, Taher A, Islam SMA, Hossain MZ (2004). Effect of variety and plant growth regulators in MS medium on shoot induction from virus infected calli of tomato. J Biol Sci 4:52-526.

Frary A, Earle ED (1996). An examination of factors affecting the efficiency of Agrobacterium-mediated transformation of tomato. Plant Cell Rep 16:235-240.

Fraser PD, Bramley PM (2004). The biosynthesis and nutritional uses of carotenoids. Prog Lipid Res 43:228-265.

Gamburg KZ, Semenova LA (1997). Clonal propagation, flowering and fruiting of tomato in vitro. Acta Hort 447:147148.

Gerster H (1997). The potential role of lycopene for human health. J Am College Nutr 16:109-126.

Gomez KA, Gomez AA (1984). Statistical procedures for agricultural research. $2^{\text {nd }}$ Ed. John Wiley and Sons, Singapore, $627 \mathrm{p}$.

Gubis J, Lajchova Z, Farago J, Jurekova Z (2003). Effect of genotype and explant type on shoot regeneration in tomato (Lycopersicon esculentum Mill.) in vitro. Czech J Genet Plant Breed 39:9-14.

Gubis J, Lajchova Z, Farago J, Jurekov Z (2004). Effect of growth regulators on shoot induction and plant regeneration in tomato (Lycopersicon esculentum Mill.). Biol Bratislava 59:405408.

Hamza S, Chupeau Y (1993). Re-evolution of conditions for plant regeneration and Agrobacterium-mediated transformation from tomato (Lycopersicon esculentum). J Exp Bot 44:1837-1845.

Hanus-Fajerska E (2001). Studies on the reaction in tissue culture of tomato genotypes under biotic stress. Acta Soc Bot Poloniae 70:5-10.

Harish MC, Rajeevkumar S, Satishkumar R (2010). Efficient in vitro callus induction and regeneration of different tomato cultivars of India. Asian J Biotechnol 2:178-184.

Ichimura K, Oda M (1995). Stimulation of shoot regeneration from cotyledon segments of tomato (Lycopersicon esculentum Mill.) by agar and its extract. J Jpn Soc Hortic Sci 64:135-141.

Indian Horticulture Database (2011). Mistry NC, Singh B, Gandhi CP, Kumar B (Eds.). Aristo Printing Press, New Delhi, 1-275 p.

Ishag S, Osman MG, Khalafalla MM (2009). Effects of growth regulators, explant and genotype on shoot regeneration in tomato (Lycopersicon esculentum cv. Omdurman). Int J Sustain Crop Prod 4:7-13.

Jyothi HK, Patil MG, Santhosha HM (2012). Evaluation of processing tomato (Solanum lycopersicum L.) genotypes for quantitative and qualitative traits in different seasons. Plant Archives 12:363-365.

Ling HQ, Krieseleit D, Ganal MW (1998). Effect of ticarcillin/potassium clavulanate on callus growth and shoot regeneration in Agrobactrerium-mediated transformation of 
tomato (Lycopersicon esculentum Mill.). Plant Cell Rep 17: 843-847.

Mamidala P, Nanna RS (2011). Effect of genotype, explant source and medium on in vitro regeneration of tomato. Int $\mathrm{J}$ Genet Mol Biol 3:45-50.

Moghaieb REA, Saneoka H, Fujita K (1999). Plant regeneration from hypocotyls and cotyledon explants of tomato (Lycopersicon esculentum Mill.). Soil Sci Plant Nutr 45:639-646.

Murashige T, Skoog F (1962). A revised medium for rapid growth and bioassays with tobacco tissue culture. Plant Physiol 15:473-497.

Namitha KK, Negi PS (2010). Chemistry and biotechnology of carotenoids. Crit Rev Food Sci Nutr 50:728 -760.

Namitha KK, Archana SN, Negi PS (2011). Expression of carotenoid biosynthetic pathway genes and changes in carotenoids during ripening in tomato (Lycopersicon esculentum). Food Funct 2:168-173.

Nogueira FTS, Costa MG, Figueira ML, Otoni WC, Finger FL (2001). In vitro regeneration of 'Santa Clara' tomato plantlets and its natural mutant 'Firme'. Scien Agrotec Lavras 25:36-71.

Oktem HA, Bulbul Y, Oktem E, Yucel M (1999). Regeneration and Agrobacterium-mediated transformation studies in tomato (Lycopersicon esculentum Miller). Turk J Bot 23:345348.

Park SH, Morris JL, Park JE, Hirschi KD, Smith RH (2003). Efficient and genotype independent Agrobactrerium-mediated tomato transformation. Plant Physiol 160:1253-1257.

Plastira VA, Perdikaris AK (1997). Effect of genotype and explant type in regeneration frequency of tomato in vitro. Acta Horticult 447:231-234.
Rao KV, Kiranmayee K, Pavan U, Jaya Sree T, Rao AV, Sadanandam A (2005). Induction of multiple shoots from leaf segments, in vitro-flowering and fruiting of a dwarf tomato (Lycopersicon esculentum). J Plant Physiol 162: 959-962.

Rao AV, Rao LG (2007). Carotenoids and human health. Pharmacol Res 55: 207-216.

Rashid R, Bal SS (2010). Effect of hormones on direct shoot regeneration in hypocotyl explants of tomato. Not Sci Biol 2:70-73.

Sarker RH, Islam K, Hoque MI (2009) In vitro regeneration and Agrobacterium-mediated genetic transformation of tomato (Lycopersicon esculentum Mill.). Plant Tissue Cult Biotech 19:101-111.

Selvi DT, Khader MA (1993). In vitro morphogenetic capacity of tomato (Lycopersicon esculentum Mill.) var. PKM.1. South Ind Horticult 41:251-258.

Sheeja TE, Mondal AB, Rathore RKS (2004). Efficient plantlet regeneration in tomato (Lycopersicon esculentum Mill.). Plant Tissue Cult 14:45-53.

Shi J, Le Mageur M (2000). Lycopene in tomatoes: chemical and physical properties affected by food processing. Crit Rev Food Sci Nutr 40:1-42.

Vikram G, Madhusudhan K, Srikanth K, Laxminarasu M, Rama Swamy N (2011). Effect of plant growth regulators on in vitro organogenesis in cultivated tomato. J Res Biol 4: 263-268.

Villiers RPD, Vuuren RJV, Ferreira DI, Staden JV (1993). Regeneration of adventitious buds from leaf discs of Lycopersicon esculentum cv. Rodade: optimization of culture medium and growth conditions. J S Afr Soc Hort Sci 3:24-27. 